ENTREPRENEURSHIP AND SUSTAINABILITY ISSUES

ISSN 2345-0282 (online) http://jssidoi.org/jesi/ 2020 Volume 8 Number 1 (September)

http://doi.org/10.9770/jesi.2020.8.1(48)

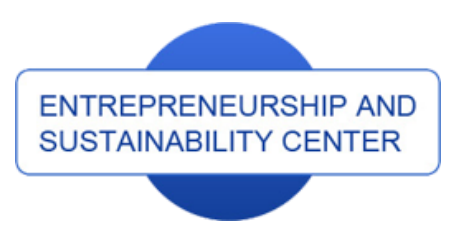

Publisher

http://jssidoi.org/esc/home

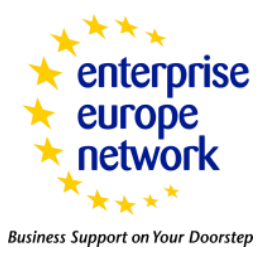

CASPA

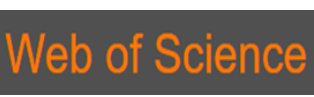

1) Clarivate

Analytics

\title{
RURAL ENTREPRENEURSHIP: TOWARDS COLLABORATIVE PARTICIPATIVE MODELS FOR ECONOMIC SUSTAINABILITY
}

\author{
Wawan Dhewanto ${ }^{1}$, Sudrajati Ratnaningtyas ${ }^{2}$, Anggraeni Permatasari ${ }^{3}$, Grisna Anggadwita ${ }^{4}$, \\ Eko Agus Prasetio 5 \\ ${ }^{1,2,5}$ School of Business and Management, Bandung Institute of Technology, Bandung, Indonesia \\ ${ }^{3}$ Faculty of Business, President University, Bekasi, Indonesia \\ ${ }^{4}$ School of Economics and Business, Telkom University, Bandung, Indonesia \\ E-mails: ${ }^{1} \underline{w}$ dhewanto@sbm-itb.ac.id $;{ }^{2}$ sudrajati@sbm-itb.ac.id $;{ }^{3}$ anggraeni@president.ac.id; \\ ${ }^{4}$ grisnaanggadwita@telkomuniversity.ac.id ; ${ }^{2}$ eko.prasetio@sbm-itb.ac.id
}

Received 20 January 2020; accepted 30 June 2020; published 30 September 2020

\begin{abstract}
Rural entrepreneurship development is one of the strategies for encouraging the acceleration of rural development by focusing on the exploration of local resources. The role of rural entrepreneurship is crucial in creating new economic activities that can help to reduce unemployment and poverty, especially in rural areas. One of the Indonesian government's programs for encouraging rural entrepreneurship is establishing BUMDes - a village-owned enterprise. This study aims to propose a participatory rural development model to optimize stakeholder collaboration in promoting local economic growth in rural areas. This study uses a qualitative method with a multicase study approach. There are three BUMDes from three regencies in West Java, Indonesia participated in this research. Triangulation used to check the validity of the data by comparing the results of interviews, FGD's, observations and secondary data. The results of the study found three sustainability dimensions to measure the success of BUMDes performance such as economic sustainability, social sustainability and market sustainability. The results suggest a collaborative model to optimizing BUMDes performance. The new model illustrates the collaboration between stakeholders to pursue rural entrepreneurship sustainability.
\end{abstract}

Keywords: rural entrepreneurship, participatory rural development, local economic, economic sustainability, BUMDes, stakeholder

Reference to this paper should be made as follows: Dhewanto, W., Ratnaningtyas, S., Permatasari, A., Anggadwita, G., Prasetio, E. A. 2020. Rural Entrepreneurship: Towards Collaborative Participative Models for Economic Sustainability. Entrepreneurship and Sustainability Issues, 705-724. http://doi.org/10.9770/jesi.2020.8.1(48)

JEL Classifications: O18, L26, R11

* The authors would like to thank to Bandung Institute of Technology (ITB), Indonesia who provide P3MI research grant. 


\section{ENTREPRENEURSHIP AND SUSTAINABILITY ISSUES}

ISSN 2345-0282 (online) http://jssidoi.org/jesi/

2020 Volume 8 Number 1 (September)

http://doi.org/10.9770/jesi.2020.8.1(48)

\section{Introduction}

Entrepreneurship growth in a country is one of a nation's welfare indicators. Entrepreneurship is the driving force for economic development by posit of creating employment, welfare, and innovation (Raudeliūniené, 2014). The role of entrepreneurship is crucial in creating new economic activities in rural areas (Ansari et al., 2013; Chatterjee et al., 2017). However, sustainability of rural entrepreneurship is a challenge because it requires integration between human resources and natural resources in the village. Sustainable entrepreneurship in the rural context implies various obstacles including lack of resources, networks or expertise (Muñoz \& Kimmitt, 2019; Chitsaz et al., 2019) due to the emphasis on high growth, high technology, and innovative entrepreneurship that dominates the current approach (Luda, 2011; Autio et al., 2014).

Rural entrepreneurship development model has been widely applied in various countries such as OVOP (One Village One Product) in Japan and OTOP (One Tambon One Product) in Thailand (Kurokawa, 2009; Natsuda et al, 2012). OVOP is also known as "strategy to develop value based on local available resources in rural area" (Issa \& Lawal, 2014). The success of these programs shows that developing entrepreneurial activity in rural areas is highly crucial. The success of OVOP and OTOP programs has spread widely in every nation, especially in developing countries. Many developing countries attempt to develop an inclusive entrepreneurial program with the same concept as OVOP and OTOP. Entrepreneurial activities will increase the number of entrepreneurs and reduce the amount of unemployment so that inequality and the social discrepancy can be overcome (Dhewanto et al., 2012, Dhewanto et al., 2016). Vietnam follows the concept of OVOP with a program called One Commune One Product (OCOP) as a strategy to generate employment opportunities, incomes and enhance creativity and capability of local people (Thanh et al., 2018). So, how about Indonesia? What kind of rural entrepreneurship development program has been established in Indonesia?

Village-Owned Enterprise (Badan Usaha Milik Desa or BUMDes) is one of the rural entrepreneurship development programs in Indonesia. Based on the BUMDes report, from 74,910 villages in Indonesia, 25\% of them have established BUMDes while the remaining 75\% have not. Among the 18,446 BUMDes that have been established, only $20 \%$ of the villages have run their BUMDes. The rest of these villages have not yet operated their BUMDes well (Bumdes.id, 2019). The results of the study indicate that the implementation of the BUMDes model has not been optimally successful. Many BUMDes have stopped their operation due to many challenges and obstacles. One of the obstacles is the absence of strong natural resources to be exploited as their economic potencies. Therefore, the objective of this research is to identify the problems and challenges that are faced by BUMDes implementation, focusing on rural areas that lack potencies on natural resources. This study adopts a place-based lens (Creswell, 2013) to understand the meso-level holistic context for the implementation of rural entrepreneurship. This research examines the feasibility of the rural entrepreneurship participatory model implemented in three BUMDes in West Java, Indonesia and the strength of the model contribution in achieving the goals of BUMDes program.

This study offers three main contributions to foster a broader discussion of rural entrepreneurship. First, based on our results, we propose a collaborative participatory rural entrepreneurship model to encourage collaboration between villagers and various stakeholders to strengthen the local economy of rural areas. Second, the results of this study enable important contributions to research and entrepreneurial-related policies in a rural context. Third, the findings and the conceptual model developed are useful for the evaluation and decision-making process from a policy perspective.

Next, we discuss a literature review of rural entrepreneurship programs, village-owned enterprise (BUMDes) and the empirical context of the implementation of them in West Java, Indonesia. Afterwards, the research method used in this study is explained. The findings in this study are presented in the following section with the proposed 


\section{ENTREPRENEURSHIP AND SUSTAINABILITY ISSUES}

ISSN 2345-0282 (online) http://jssidoi.org/jesi/

2020 Volume 8 Number 1 (September)

http://doi.org/10.9770/jesi.2020.8.1(48)

model of rural entrepreneurship sustainability. Finally, we discuss some of the implications of our research on the theory of rural entrepreneurship.

\section{Literature Review}

\subsection{Rural Entrepreneurship}

According to Yang, Cerneviciute, \& Strazdas (2020), the performance of rural areas is determined by troupes that emerge as new forces in improving welfare, one of which is entrepreneurial activity. Chitsaz et al. (2019) stated "the difference between rural entrepreneurship and entrepreneurship lies in the special conditions of rural areas such as the high risk, lack of facilities, and weak management". Similarly, Ansari et al (2013) acknowledged that "rural entrepreneurship considered as one of the solutions to reduce poverty, migration and develop employment in rural areas". Additionally, other studies also define it as local economic-based entrepreneurial activities (McElwee \& Atherton, 2011). Rural entrepreneurship creates a new combination of resources, based on the place or local area and results in value for both entrepreneurs and the local area (Müller \& Korsgaard, 2018). Thus, the purpose of rural entrepreneurship is to foster the enthusiasm of youth and rural communities to explore the potential in their area (local potential) through entrepreneurship (Larasdiputra et al., 2019).

Rural entrepreneurship is one of the most important solutions for sustainable rural development (Ansari et al., 2013). Meera \& Vinodan, 2018 stated "rural entrepreneurship seeks to identify new opportunities, innovation, creativity in agricultural and non-agricultural activities, and tourism". Rural entrepreneurship is a local economic development that involves government and community organizations. Olafsen \& Cook (2016) described local economic development as a process whereby development actors work collectively with partners from the public, private and non-government sectors, to create changes and better conditions for economic growth and employment opportunities. According to Alheet (2019), entrepreneurial activities have a positive effect on economic growth (GDP growth). Therefore, this effect indicates that the implementation of entrepreneurship activities in villages contributes to economic growth in villages (Ansari et al., 2013; Meera \& Vinodan, 2018).

According to Raudeliūnienè et al. (2014), "sustainable entrepreneurship is a concept that combines and balances two dimensions of economic goals and social ecological goals, creating viable economic performance of business enterprise". As mentioned above, the regional government and/or community-based groups manage available resources to create employment opportunities and strengthen regional economic activities. These resources are characterized based on the potential of local human resources, institutions, and physical resources. Undoubtedly, local economic growth that has improved through the development practice in rural areas is considered as a socioeconomic impact (Raudeliūnienè et al, 2014; Goyal \& Sergi, 2015). This is in line with Baierl et al. (2014) that defined social impact as changes occur in humans and societies that arise from development activities such as programs, projects or policies that are applied to the community.

Several studies have identified the role of entrepreneurship in rural economic growth and development (Goetz et al., 2010). Some focus on its sustainability rural entrepreneurship (Luda, 2011; Ansari et al., 2013), marketing (Polo-Peña et al., 2012), and some on human and social capital (Chitsaz et al., 2019). Additionally, rural economic activities require social relationships that have an important role in growing trust and expanding networks. Furthermore, the importance of policies and strategies to support entrepreneurship development has been explored (Ansari et al., 2013). Therefore, a more strategic and coordinated approach is needed to build entrepreneurial capacity in rural areas (Welter, 2011; Chitsaz et al., 2019), so the rural can perform well. 


\section{ENTREPRENEURSHIP AND SUSTAINABILITY ISSUES}

ISSN 2345-0282 (online) http://jssidoi.org/jesi/

2020 Volume 8 Number 1 (September)

http://doi.org/10.9770/jesi.2020.8.1(48)

\subsection{Village-owned Enterprise (BUMDes)}

The village-owned enterprise (BUMDes) is one of the implementations of the rural entrepreneurship program initiated by the Indonesian government. The implementation of the program has strong relationships with the concept of Community-Based Enterprises (CBEs). CBEs can be formed as a result of a local community's entrepreneurial activities, by employing their social resources, structures and networks (Natsuda et al., 2012). Indonesian Law No. 6 of 2014 about Villages provides great opportunities for the development of villages. According to the law, the village has the authority to manage its own assets, including the management of the village economy. The problems of village economic need to be resolved with comprehensive handling, including the construction of infrastructure facilities, the economic potential development of the village, and this potential optimization for the village communities' welfare (Kania, Akbar, \& Budiman, 2019).

BUMDes is a policy implementation rolled out by the Ministry of Village and Transmigration to facilitate infrastructure development support and expand the productive economic efforts in rural communities. BUMDes is a form of village economic independence by moving strategic business units to the collective village ownership by optimizing village assets and empowering community businesses and increase the income of village communities (Purbasari, Soeling, \& Wijaya, 2019).

Moreover, BUMDes is an institution formed by the village government and the community to fulfil the economic needs of the village. BUMDes is established to accommodate all activities in the economic sector and/or public services managed by villages and/or communities, and not merely for profit (Kusuma \& Krisnadewara, 2019). BUMDes has contributed positively to rural development, especially in the economic and social fields through economic empowerment and growth (Sudaryana, 2016; Purbasari, Soeling, \& Wijaya, 2019).

BUMDes is formed as a village business institution that functions to improve the welfare of citizens by utilizing the assets and village potential with the allocation of village capital. The urgency of BUMDes establishment in Indonesia is emphasized in the Regulation of the Minister of Villages, Development of Underdeveloped Regions, and Transmigration (Permendesa) No. 4 of 2015. It describes BUMDes as "business entities whose entire or part of their capital is owned by the village through direct participation originating from village assets separated to manage assets, services, and other businesses for the greatest welfare of the village community". Additionally, the Minister of Home Affairs Regulation No. 39 of 2010 recognizes BUMDes as a village business entity with a spirit of independence, togetherness and cooperation between the village government and the community. The presence of BUMDes is expected to be the driving force of the village economy, not only to generate institutional profits but also to provide both economic and social benefits for the villagers (Sudaryana, 2016).

\subsection{Research Context: Village-owned Enterprise (BUMDes) in West Java, Indonesia}

West Java is a province in Indonesia that consists of 18 regencies and 9 cities. To this day, the number of BUMDes in West Java has reached 2,921 (Ministry of Villages, Development of Underdeveloped Areas, and Transmigration, 2020). However, its implementation faces several obstacles and challenges which is evidenced by growth failure and discontinuation of many of these village-owned enterprises. One such reasons is that the BUMDes concept was adopted from the OVOP program, which focuses more on establishing enterprises rather than marketing its products. This had implicated failure for many BUMDes products in the market.

Therefore, the Government of West Java Province developed a one-village one company (OVOC) program aimed to increase local economic growth and provide employment opportunities in rural areas. The program also intended to support the sustainability of BUMDes programs in West Java. Compared to BUMDes, the feasibility of the enterprises has been tested by validating product-market fit. The West Java government's priority strategic plan for the period 2018-2023 is to solve the problem of unemployment and increase economic growth based on 


\section{ENTREPRENEURSHIP AND SUSTAINABILITY ISSUES}

ISSN 2345-0282 (online) http://jssidoi.org/jesi/

2020 Volume 8 Number 1 (September)

http://doi.org/10.9770/jesi.2020.8.1(48)

potential local resources. One of its government programs is One Village One Company (OVOC), an umbrella program that aims to emancipate villages by utilizing and optimizing the potential of both human and natural resources by Village-Owned Enterprise (BUMDes) (One Village One Company, 2020). The goal of the program is to boost economic activity and improve community welfare in rural areas.

Therefore, this study examines the implementation of the program to support BUMDes performance. This study also identifies the implementation of a participatory rural entrepreneurship program to help communities to improve their local economic growth in three regencies in West Java: Bandung, Bekasi and Garut.

\section{Research Methods}

\subsection{Research Design}

This research was employed using a qualitative method with case study design. The qualitative method was selected to have in-depth understanding, description and a detailed explanation about social phenomena (Saunders \& Lewis, 2012). While, case study is defined as "an empirical inquiry that investigates a contemporary phenomenon (the 'case') in depth and within its real-world context" (Yin, 2014). For this research, multiple case studies were examined to illustrate the phenomena of rural entrepreneurship development in West Java, Indonesia. The multiple case studies is an approach that utilizes more than a single issue or case on single research (Creswell et al, 2013). Gustafsson (2017) also stated that multiple cases used to understand the differences and the similarities between the cases. Therefore, this study focusing on unique cases of BUMDes as village-owned enterprises from West Java Province, Indonesia. We believes that multiple cases method is capable to understand the context of BUMDes. The other benefit from multiple cases method is able to analyse the data within across different situations.

\subsection{Sample Design}

According to Yin (2014), in multiple case studies, "the researcher has to identify the case and the specific type of the case that shall be implemented". A sample design is road map to define sample selection. This study used purposive sampling technique based on the priority of sustainability issues. This research focused on three regencies in West Java: Bandung, Bekasi and Garut. Those three regencies have 743 BUMDes. However, only 273 are active while 470 require further development (One Village One Company, 2020). Next, we choosed three active BUMDes to participate as a sample. An active BUMDes is an enterprise that is managed based on the laws and regulations, through the management of village assets and potential activities and is not only oriented towards institutional profit. The sample units (BUMDes) were selected based on few characteristics. First is the complexity of the problems in each rural area. Second is the year of establishment. They are the BUMDes that have already implemented participatory rural entrepreneurship in their respective village for more than two years. The last is the uniqueness. The uniqueness of these samples is related to their success in developing BUMDes based on human resource capability and economic potential rather than natural resources that support their area. The three BUMDes selected have different potencies such as human resource, natural resource and technology. From those point of view, we notice the three BUMDes are the perfect samples for collaborative model to support BUMDes sustainability.

\subsection{Data Collection}

The research is based on social context; therefore the data was gathered from field observations, in-depth interviews and Focus Group Discussion (FGD) with local entrepreneurs and stakeholders. Further observation was carried out by directly observing business processes and relevant documents in the BUMDes of the three 


\section{ENTREPRENEURSHIP AND SUSTAINABILITY ISSUES}

ISSN 2345-0282 (online) http://jssidoi.org/jesi/ 2020 Volume 8 Number 1 (September) http://doi.org/10.9770/jesi.2020.8.1(48)

regencies. Semi-structured interviews were conducted face-to-face with each informant, and follow-up interviews were conducted by telephone for additional questions. Informants were appointed based on recommendations from Regency Government Institution in Rural and Communities Development. There are a total of twelve informants that participated in this research. The interviews lasted between 60 to 120 minutes and were digitally recorded and transcribed verbatim. Then, the findings during individual interviews were reconfirmed with all informants through an FGD session. Next, we mapped the relationships between BUMDes actors and clarified some of the social ties of the informants, especially the BUMDes top managements, the government, and the community. Information from these sources enabled us to reexamine data and improve consistency and reliability.

The profile of the informants is shown in Table 1. Referring to the table, the majority of key informants are actors who have a role in succeeding the BUMDes program. Among the participants are civil servants from Local Village and Community Village Empowerment Agency (Dinas Pemberdayaan Masyarakat dan Desa or DPMD), BUMDes Chairperson, Association Chairperson and the community. All informants respond well to the questions and understand the problems that occurred in the management of BUMDes.

Table 1. Informant Profiles

\begin{tabular}{|c|c|c|l|}
\hline No. & Code & Gender & \multicolumn{1}{|c|}{ Position of Informant } \\
\hline 1 & BA1 & M & Staff-DPMD Bandung \\
\hline 2 & BA2 & F & Director-BUMDes A \\
\hline 3 & BA3 & F & Community \\
\hline 4 & BK1 & M & Head of BUMDes Association in Bekasi \\
\hline 5 & BK2 & F & Co-Head of BUMDes Association \\
\hline 6 & BK3 & M & Director of BUMDes B \\
\hline 7 & BK4 & M & Member of BUMDes Association \\
\hline 8 & BK5 & F & Staff-DPMD Bekasi \\
\hline 9 & BK6 & M & Staff-DPMD Bekasi \\
\hline 10 & GR1 & F & BUMDes Team Coordinator in Garut \\
\hline 11 & GR2 & F & BUMDes Developer in Garut \\
\hline 12 & GR3 & M & CEO Holistika Institute-BUMDes Trainer \\
\hline
\end{tabular}

\subsection{Data Analysis}

Data analysis was performed to provide a better understanding of each case study by describing the findings of the collected data. This research adopted an inductive approach for the category in the first level, to the theme at the second level and related theoretical dimensions at the third level. This allowed us to identify themes and patterns that emerge in each case (Gioia, Corley, \& Hamilton 2013). Additionally, the researcher also employed a comparative study to interpret the relationships that arise among different concepts and further compared these patterns in the three case studies. The comparative information for each case is presented in a table to clarify the context and enhance the credibility of our analysis. Triangulation also was used to validate the interrelation of data from the field research (Saunders \& Lewis, 2012). Finally, the data interpretation was illustrated on a model implication of the local economic development and local resources management toward rural sustainability in West Java. 


\section{Findings}

\subsection{Multiple Case Studies}

This section presents three cases of BUMDes implementation in three differences regencies of West Java. We provide an overview of each case at BUMDes based on our exploration and analysis.

\subsubsection{Case 1. BUMDes A}

The Table 2 below shows the profile of BUMDes A as one of the case studies in this research. BUMDes A was established in Wangisagara village in 2002 through a community forum (musyawarah). This BUMDes is the oldest and most advanced commerce in the Bandung Regency. Last year, BUMDes Niagara won $2^{\text {nd }}$ place in the BUMDes award in West Java Festival 2019.

Table 2. BUMDes A Profile

\begin{tabular}{|c|c|}
\hline \multicolumn{2}{|l|}{ BUMDes A } \\
\hline Regency & Bandung \\
\hline Province & West Java \\
\hline District & Majalaya \\
\hline Rural/Village & Wangisagara \\
\hline Area & $195 \mathrm{Ha}$ \\
\hline Population & 15.546 \\
\hline BUMDes Established & 2002 \\
\hline Equity (Start-up) & IDR 150 Million \\
\hline Last Year Income (2018) & IDR 1.6 Billion \\
\hline Achievement & $2^{\text {nd }}$ place in the BUMDes award in West Java Festival 2019 \\
\hline Business Scale & Growing \\
\hline Product/Services & $\begin{array}{ll}\text { - } & \text { Trading (traditional market) } \\
\text { - } & \text { Credit Finance } \\
\text { - } & \text { Manufacturing industry based on Local Resource (Sandals, Mineral Water) }\end{array}$ \\
\hline
\end{tabular}

BUMDes A refers to a business model in implementing their business, and they claim that it is one of the best example of the BUMDes business model in Indonesia. BA1 stated:" the great example of BUMDes Model is BUMDes A because the business grows significantly" BUMDes A has three business divisions, such as village market (traditional-trading), credit finance, and manufacturing industry (mineral water and sandal production). BUMDes A explores the potential of villages to help the people to earn income. According to the informant BA2,"the key success factors of BUMDes $A$ are the potentials of human resources and economic owned by Wangisagara communities. Those potencies are captured and utilized by BUMDes A."

BUMDes Niagara plans a specified target to be achieved every year. The target measures the existence of BUMDes A positive impact on community welfare. The expected positive impact is that BUMDes A can provide the necessary assistance to every community with business potentials to be developed. BUMDes A collaborates with third parties such as financial institutions to help communities with funding to expand their business. It also cooperates with several universities for assistance in developing the marketing strategy. The implementation of the business model at BUMDes A has proven successful. Informant BA2 conveyed, "the success factor of BUMDes is the team management, including technicians and experts, that demonstrates good leadership". However, BUMDes A still faces obstacles such as business management development, particularly in marketing and financial aspects. 


\subsubsection{Case 2. BUMDes B}

BUMDes B has been established since 2017 in Simpangan, Bekasi Regency. BUMDes B located in Cikarang Utara District, surrounded by manufacturing industry area. Table 3 below shows the profile of BUMDes B.

Table 3. BUMDes B Profile

\begin{tabular}{|c|c|}
\hline \multicolumn{2}{|l|}{ BUMDes B } \\
\hline Regency & Bekasi \\
\hline Province & West Java \\
\hline District & Cikarang Utara \\
\hline Rural/Village & Simpangan \\
\hline Area & $310 \mathrm{Ha}$ \\
\hline Population & 31.825 \\
\hline BUMDes Established & 2017 \\
\hline Equity & IDR 160 Million \\
\hline Last Year Income (2018) & IDR 800 Million \\
\hline Achievement & 1st Winner BUMDes Award in Bekasi Regency 2018 \\
\hline Business Scale & Growing \\
\hline Product/Services & $\begin{array}{l}\text {-Trading (BUMDes Mart, POM -Mini, Stationary, Photocopy) } \\
\text { - Credit Finance } \\
\text { - Manufacturing Industry based on Local Resources (Sandals, Snack, Craft, } \\
\text { Waste Bank) }\end{array}$ \\
\hline
\end{tabular}

The manufacturing industry has reduced the potential of natural resources in Cikarang region. Thus, the biggest potencies are from human and economic resources. BUMDes B has developed three business units such as trading, credit finance and home industry manufacture. Another potency of BUMDes B is waste management generated from their manufacturing industry, which they have successfully managed. The company was established with IDR 160 Million equity from Rural Budget. In 2018, the turnover has reached IDR 800 Million. BK2 mentioned:" now since the profit of BUMDes has reached the break-even point, we can support funding for rural development". BUMDes B may still be new or an infant, but they exhibit good performances, especially this year. In 2018, BUMDes B won the $1^{\text {st }}$ Winner of BUMDes Award Competition in Bekasi Regency.

\subsubsection{Case 3. BUMDes C}

BUMDes C was established in 2016 in the Cigawir village, Selaawi District, Garut Regency. The establishment of BUMDes $\mathrm{C}$ was chosen as an alternative to developing the economy in the Cigawir village. Table 4 below shows the profile of BUMDes C. The establishment of BUMDes C is regulated in the Village Regulation (Perdes) No. 3 of 2016. It has been established and operating since 2016 with IDR 150 million funding. Initially, their primary business units were in trading such as photocopying, stationery and food stall businesses. In 2018, BUMDes C has gained capital to improve the agricultural sector. In 2019, it won the $2^{\text {nd }}$ place in the Appropriate Technology (TTG) competition held in Garut Regency. BUMDes C has produced an innovative internet signal capture repeater transmitter. This innovative product is very useful in accelerating the economic growth of Cigawir and surrounding villages. However, based on observations and interviews, the presence of BUMDes $\mathrm{C}$ has few impacts to stimulate and move the wheels of the village economy. 
ENTREPRENEURSHIP AND SUSTAINABILITY ISSUES

ISSN 2345-0282 (online) http://jssidoi.org/jesi/ 2020 Volume 8 Number 1 (September) http://doi.org/10.9770/jesi.2020.8.1(48)

Table 4. BUMDes C Profile

\begin{tabular}{|l|l|}
\hline BUMDes C & Garut \\
\hline Regency & West Java \\
\hline Province & Selaawi \\
\hline District & Cigawir \\
\hline Rural/Village & $510.5 \mathrm{Ha}$ \\
\hline Area & 5.095 \\
\hline Population & 2016 \\
\hline BUMDes Established & IDR 150 Million \\
\hline Equity & IDR 730 Million \\
\hline Last Year Income (2018) & 1st Winner in Appropriate Technology Competition in Garut Regency 2019 \\
\hline Achievement & Developed \\
\hline Business Scale & - Trading (Stationary, Photocopy) \\
\hline Product/Services & - Farming Fertilizer \\
& - Public Services (IT Development) \\
\hline
\end{tabular}

\subsection{Case Studies Analysis}

Based on the interview, we highlighted several important findings that emerged from the analysis results. This insight was employed to develop propositions about how the BUMDes approach can effectively encourage rural entrepreneurship. Additionally, the findings were also used as a basis for proposing a participatory rural development model to optimize stakeholder collaboration in promoting local economic growth in rural areas. Figure 1 below provides an overview of the findings. All concepts and themes that emerge from the data are given in this figure. 


\section{ENTREPRENEURSHIP AND SUSTAINABILITY ISSUES}

ISSN 2345-0282 (online) http://jssidoi.org/jesi/ 2020 Volume 8 Number 1 (September) http://doi.org/10.9770/jesi.2020.8.1(48)

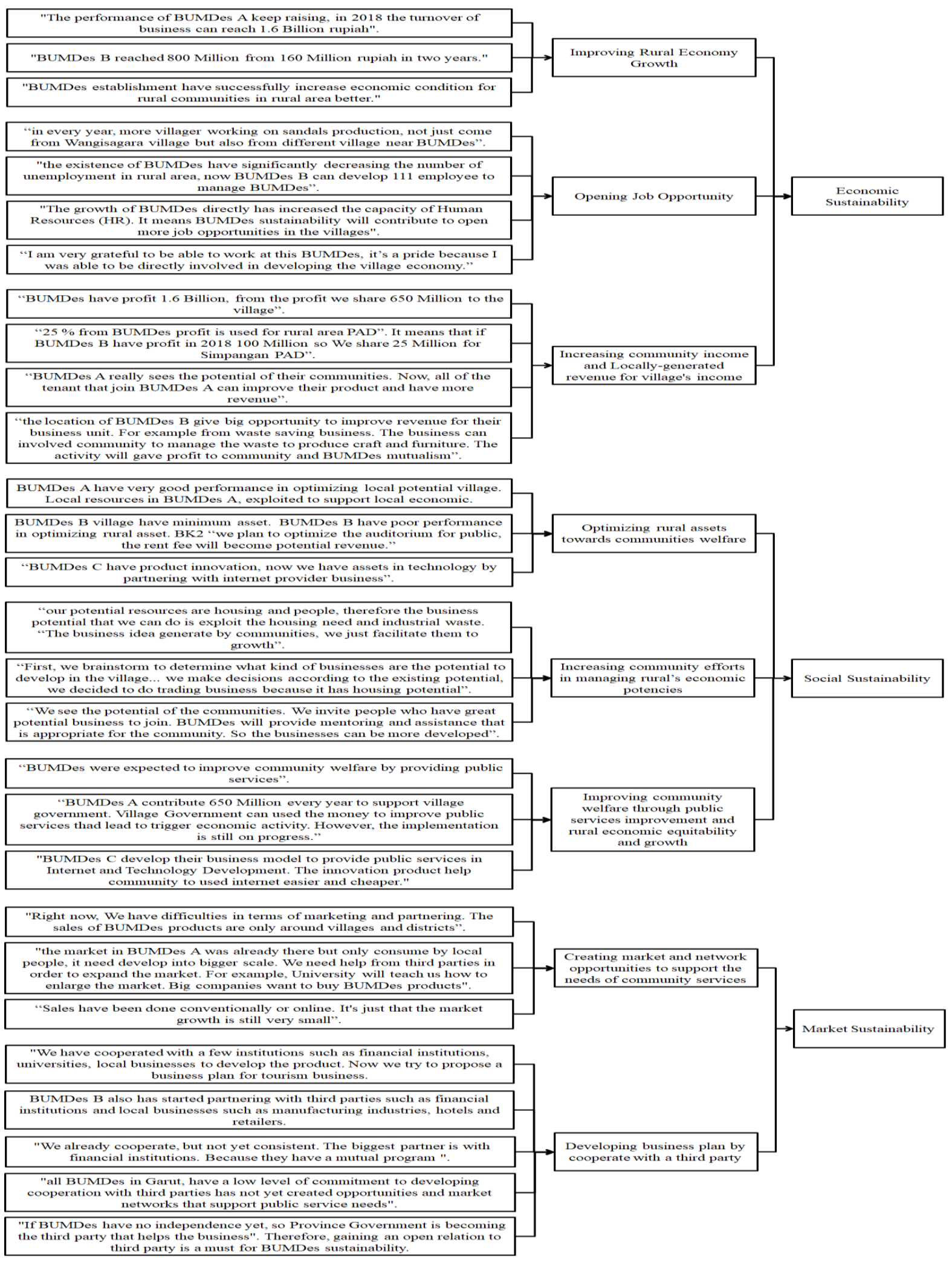

Fig 1. The Dimension and Factors of BUMDes for Economic, Market and Social Sustainability 


\section{ENTREPRENEURSHIP AND SUSTAINABILITY ISSUES}

ISSN 2345-0282 (online) http://jssidoi.org/jesi/

2020 Volume 8 Number 1 (September)

http://doi.org/10.9770/jesi.2020.8.1(48)

Figure 1 above shows the results of interviews with key informants using the inductive approach, where the analysis of interview results at the first level, identification of factors at the second level, and identification of dimensions at the third level (Gioia, Corley, \& Hamilton 2013). We identified 8 factors related to BUMDes as rural entrepreneurship programs including improving rural economy growth, opening job opportunity, increasing community income and locally-generated revenue for village's income, optimizing rural assets towards communities welfare, increasing community efforts in managing rural's economic potencies, improving community welfare through public services improvement and rural economic equitability and growth, creating market and network opportunities to support the needs of community services, and developing business plan by cooperate with a third party. These factors are in accordance with the objectives of establishing BUMDes stated in Regulation of the Minister of Villages, Development of Underdeveloped Regions, and Transmigration (Permendesa) No. 4 year 2015. Based on the results of the analysis, we grouped these 8 factors into 3 dimensions (economic sustainability, social sustainability, and market sustainability). To show themes and patterns that emerge in the case studies, these factors are grouped based on the similarity of characteristics and objectives of the BUMDes program. The explanation of every dimensions and its factors will be further discussed below.

\subsubsection{Economic Sustainability}

The underlying theory claimed that "there is a positive relationship between entrepreneurship and economic growth in a country both in the short and long term" (Alheet, 2019). So, it can be implied that BUMDes is an alternative strategy to improve the rural economy. The results show that BUMDes A, B and C demonstrate good performances on improving rural economic growth. BUMDes A started from equity support from the village around IDR 150 Million in 2002. The performance keeps increasing, with the turnover of business reached up to IDR 1.6 Billion in 2018. Meanwhile, BUMDes B has reached IDR 800 Million from IDR 160 Million in two years. The growth performance has proven that BUMDes A, B and C have significant impacts on local economic development in rural areas. All the BUMDes informants have the same perception that the establishment of BUMDes has succeeded in better improving economic conditions for rural communities.

BUMDes performances also increase the number of start-up businesses in rural areas and improve the income for several business units that were established. However, the impact of BUMDes is measured by not only the economic aspect but also the social aspect. On the social aspect, improvements can be seen through the increasing number of community welfare, job opportunity and public services. Overall, the impacts of BUMDes A, B and C performances are more visible if measured from the economic aspect.

The rural entrepreneurs are the key drivers for job creation and welfare in villages (Chatterjee et al, 2017). BUMDes A, B and C have fair success in recruiting unemployed villagers. The result shows that the existence of BUMDes positively affects the opening of job opportunity in rural areas. However, the quantity of business still cannot provide sufficient job opportunity for the entire villagers. For example, in BUMDes A, the development of sandal production creates job opportunities in the village. BA2 stated: "in every year, more villagers will be working on the sandal production. They come from not only Wangisagara village but also different villages near BUMDes". Informant BK4 also mentioned that "the existence of BUMDes has significantly decreased the number of unemployment in rural areas. Now, BUMDes B can employ 111 employees to manage BUMDes". BK 5 added that "I am very grateful to be working at this BUMDes. It's pride because I can be directly involved in developing the village economy." GR 1 also conveyed that "the growth of BUMDes has directly increased the capacity of Human Resources (HR). It means that BUMDes sustainability will contribute to creating more job opportunities in the villages".

The most important role of BUMDes is to increase rural economic growth. There is no perfect instrument to measure the impact of BUMDes performance on the village income. However, it can be perceived from BUMDes 


\section{ENTREPRENEURSHIP AND SUSTAINABILITY ISSUES}

ISSN 2345-0282 (online) http://jssidoi.org/jesi/ 2020 Volume 8 Number 1 (September) http://doi.org/10.9770/jesi.2020.8.1(48)

contributions to it. The finding shows that BUMDes $\mathrm{A}$ and $\mathrm{B}$ performances have significant contributions to increase village income in rural areas, signified by the revenue sharing from BUMDEs. For example, BUMDes A contributes IDR 650 million annually for the income of Wangisagara village. BA2 stated: "BUMDes has profited IDR 1.6 Billion, and we allocate IDR 650 Million for the village”. Meanwhile, BUMDes B, as disclosed by BK1 that "25\% of the BUMDes profit is allocated as rural area village income. It means that if BUMDes B earned IDR 100 Million in 2018, we assigned 25 Million as the income of Simpangan village". It is concluded that BUMDes positively contributes to increasing rural income.

Overall, BUMDes performance of this study in increasing community income is sufficient. Based on the interviews, communities can increase their business income significantly through BUMDes. For example, one of the sandal crafters in BUMDes A previously only produced sandals and had funding constraints to improve the product. Now after joining BUMDes A, the community receives funding to increase production and marketing assistance. BA2 expressed that "BUMDes A really sees the potential of their communities. Now, all tenants that join BUMDes A can improve their products and earn more revenue". BA3 said that "the average daily income of my business has increased up to around IDR 300 thousand" - and more if there is an event. In Bekasi Regency, BUMDes B has successfully managed waste from the nearby manufacturing industry to increase village income. BK2 mentioned that "the location of BUMDes B provides a big opportunity to improve revenue for their business unit such as waste management. It can employ the community to manage the waste and produce crafts and furniture. The activity will yield a profit for the community and BUMDes mutualism". Generally, BUMDes earns great income in savings and loan businesses (credit finance) as the priority programs. However, BUMDes needs to explore wider opportunities from different business sectors.

\subsubsection{Social Sustainability}

The finding shows that BUMDes A exhibits good performance in optimizing the local village potential, such as the traditional market building. BUMDes A also maximizes the mineral water industry by involving communities in its production. In the future, the company plans to build sports facilities and tourist attractions. On the other hand, BUMDes B performs poorly in optimizing rural assets due to the village's relatively small assets and BUMDes being newly operated. The only asset owned by BUMDes B is the Auditorium. BK2 disclosed that "next year, we plan to optimize the auditorium for the public; the rental fee could become the potential revenue". Meanwhile, BUMDes $\mathrm{C}$ performance in optimizing asset is fair. Presently, BUMDes $\mathrm{C}$ sees business opportunities in IT development by creating innovative products to help local people. As stated by GA1, "BUMDes $C$ has performed a product innovation, now we have assets in technology by partnering with the internet service provider business". It was seen from the beginning of these BUMDes establishments, despite only had minimal assets and less natural resource potentials to improve the welfare of the community, their ventures become a driver for community economic activities.

BUMDes existence is an effort to improve the village economy based on the needs and potential of the rural area, as the respective communities have strong social and cultural ties with traditional values. These findings indicate that BUMDes A, B and C have great success in increasing community efforts to manage economic potential in rural areas. They also have great potencies in economic and human resources. For example, the Bekasi Regency location near the manufacturing industry creates potentials for housing development and waste management. BK2 mentioned that "our potential resources are housing and people. Therefore, the business potential that we can do is making use of the housing need and industrial waste". The condition is also supported by a statement from BA2, "the business idea was generated by communities; we just facilitate them to grow".

Additionally, BUMDes has also proven to empower communities in the village to start businesses. BK2 conveyed that "first, we brainstormed to determine what kind of business potential to be developed in the village. We made decisions according to the existing potential, (and then) we decided to do trading because it has housing 


\section{ENTREPRENEURSHIP AND SUSTAINABILITY ISSUES}

ISSN 2345-0282 (online) http://jssidoi.org/jesi/

2020 Volume 8 Number 1 (September)

http://doi.org/10.9770/jesi.2020.8.1(48)

potentials". BA2 also informed that "we see the potential of the communities. We invite people who have a great potential business to join. BUMDes will provide mentoring and assistance that is appropriate for the community, so the businesses can be more developed".

The great concept of BUMDes is to help community's start-ups by empowering them with knowledge and skills to grow a business. But, most of the communities only expect BUMDes for financing. Therefore, to increase the community effort, BUMDes develops business on the credit financial system. By managing this business, most of BUMDes are successful in increasing their profits.

All of the BUMDes of this study are established based on the approval from the chief of the rural area and their communities. They also allocate a budget to invest in BUMDes operational management. Hence, BUMDes management should dedicate its goals to support community welfare. BA1 stated: "BUMDes were expected to improve community welfare by providing public services". In an ideal condition, BUMDes profits will be allocated to provide good public services to the community, which will trigger economic activities in rural areas. Thus, the sustainability of BUMDes will improve community welfare. BA2 also disclosed that "BUMDes $A$ contributes IDR 650 Million annually to support the village government. The village government can use the money to improve public services that trigger economic activities. However, the implementation is still in progress." Meanwhile, BUMDes B encourages its business units to utilize internet facilities from the village for business marketing and modernizing their behavior. In another case, BUMDes C develops its business model to provide public services in Internet and Technology Development. BUMDes $\mathrm{C}$ creation is the innovative product called a repeater, a transmitter to amplify the internet signal. This product helps the community to use the internet easier and cheaper. The product is also commercialized to other villages. Therefore, BUMDes A, B and C have demonstrated good commitment to improving community welfare. Still, it calls for better coordination with the rural government and communities.

\subsubsection{Market Sustainability}

The biggest challenge to optimize BUMDes performances is creating a market. BK1 stated: "right now, we have difficulties in terms of marketing and partnering. The sales of BUMDes products are only around villages and districts". GR2 also mentioned that "sales have been done conventionally or online. It's just that the market growth is still very small”. BUMDes B hopes that there would be an intervention from the Bekasi Regency or West Java Provincial Government to create a special policy that helps the BUMDes market growth. BK2 said, "for example, BUMDESMART cannot compete with retail stores such as Alfamart and Indomaret (since) people prefer buying goods at retail stores than BUMDESMART. So, what should we do?" BA1 also added, "the market in BUMDes A is already available, but it is only consumed by the local people. It needs to develop into bigger scales. We need help from third parties to expand the market. For example, the university (professionals will) teach us how to enlarge the market (so) big companies choose to buy BUMDes products". Therefore, to fill the gap between BUMDes and the business, it needs support from provincial and regency governments. They can be intermediaries to develop a good marketing strategy for BUMDes products.

The role of BUMDes in managing local resources in rural areas is very crucial. However, the sustainability of BUMDes requires support from their stakeholder or third parties, particularly developed business institutions. Based on the results of the study, BUMDes A already has a permanent partnership with a third party to expand its business. As stated by BA2, "we have cooperated with several institutions such as financial institutions, universities, and local businesses to develop the product. Now we try to propose a business plan for a tourism business". BUMDes B has also begun to partner with third parties, such as financial institutions and local businesses, which include the manufacturing, hotel and retailer industries. BK2 mentioned that "we already cooperate (with third parties), but not yet consistent. The main partners are financial institutions because they have a mutual program". Meanwhile, BUMDes C has difficulties developing business plans with third parties. 


\section{ENTREPRENEURSHIP AND SUSTAINABILITY ISSUES}

ISSN 2345-0282 (online) http://jssidoi.org/jesi/ 2020 Volume 8 Number 1 (September) http://doi.org/10.9770/jesi.2020.8.1(48)

GR2 disclosed that "all BUMDes in Garut have a low level of commitment to developing cooperation with third parties. They have not yet created opportunities and market networks that support public service needs". In business, third party involvement is very important to expand markets and generate more benefits. GA1 also added that "if BUMDes has no independence yet, the Provincial Government should become the third party that aids the business". Therefore, securing an open relation to a third party is a must for BUMDes sustainability.

\subsection{Developing a Model of Collaborative Participatory Rural Entrepreneurship}

Indonesian Government has formally established BUMDes to implement economic empowerment programs in rural areas. Furthermore, West Java Provincial Government implement One Village One Company (OVOC) program to empower BUMDes. The existence of BUMDes will help West Java Government to provide community welfare. In practices, BUMDes adopted social entrepreneurship (hybrid) goals on creating profit and social impact. Social enterprises encourage social initiatives to overcome social problems by adopting a business approach (Goyal \& Sergi, 2015; Pratono et al., 2020). The critical role of BUMDes is as an agent for rural development changes (Baierl et al, 2014). While, Pratono et al. (2020) stated that social enterprise involves the role of stakeholders, social role, mission drifting and social performance. Therefore, BUMDes embody social enterprise character, which is focusing on solving problems in the village and increasing economic condition in the rural area.

Based on the evaluation results from the implementation of three BUMDes in three regencies, all BUMDes of this study has successfully improved goals related to economic. BUMDes A is one of the ideal models that have proven to significantly impact rural economic growth, opening job opportunity and increasing village income (Natsuda et al., 2012; Issa \& Lawal, 2014). However, BUMDes faces challenges in managing revenue to improve community welfare (the social aspect) (Baierl et al., 2014). BUMDes A \& B implementations show that the model of participatory rural entrepreneurship has significant impacts on local economic growths. The model supports BUMDes A and B to perform very well, while BUMDes C model has not been adequately implemented due to their lack of collaboration. BUMDes A, B and C also face the difficulties to expand their market and collaborate with third parties. The results supporting previous research from Tousi et al. (2014) which found that rural entrepreneurship development barriers such as "lack of financial support, lack of access to accurate information, absence of a supportive culture, and a long distance between villages and markets and services". Therefore, this research suggests a new model to overcome the barriers by providing collaboration between stakeholders in West Java Province.

The village-owned enterprise is implemented to encourage the collaboration between villagers and various stakeholders to strengthen the local economy of rural areas (Welter, 2011; and Zahra, Wright, \& Abdelgawad, 2014). This study tries to fill the gap that occurs in the implementation management by proposing a collaborative participatory rural entrepreneurship model (Figure 2). The model shows the collaboration between actors; with every BUMDes has its own potencies and business priority. The revenue from BUMDes performances will be invested in community services that support economic activity. 
ENTREPRENEURSHIP AND SUSTAINABILITY ISSUES

ISSN 2345-0282 (online) http://jssidoi.org/jesi/ 2020 Volume 8 Number 1 (September) http://doi.org/10.9770/jesi.2020.8.1(48)

\begin{tabular}{|c|c|c|}
\hline \multicolumn{3}{|c|}{ Local Potential } \\
\hline \multicolumn{3}{|c|}{ Rural Communities } \\
\hline $\begin{array}{c}\text { Village } \\
\text { Community } \\
\text { Empowerment } \\
\text { Agency }\end{array}$ & \multirow{4}{*}{ Business / Private Sector } & Association \\
\hline $\begin{array}{c}\text { District } \\
\text { Government }\end{array}$ & & $\begin{array}{c}\text { Regional } \\
\text { Government }\end{array}$ \\
\hline \multirow{2}{*}{$\begin{array}{l}\text { Higher } \\
\text { Institution/ } \\
\text { University }\end{array}$} & & \multirow{2}{*}{$\begin{array}{l}\text { Financial } \\
\text { Institution }\end{array}$} \\
\hline & & \\
\hline \multicolumn{3}{|c|}{ Central Government } \\
\hline
\end{tabular}

Fig 2. The Conceptual Model of Collaborative Participatory Rural Entrepreneurship of BUMDes

\subsection{Discussions}

Sustainable entrepreneurship is a key factor to achieve organization's uniqueness and value creation (Raudeliūnienè, 2014). Drucker (2014) stated that the challenge in the sustainability of entrepreneurship is related to one's ability to create something new and innovative. Therefore, the implementation of rural entrepreneurship model can be sustained if the model can manage their local resources and create innovation (Luda, 2011; Ramadani, et al, 2014). The role of active community participation in rural development programs has not yet been measured. Participation is an active role, although it does not always play a direct role in community decisions or affects knowledge of local issues and presence in public meetings, it impacts proposed actions through the individual, group, and community contributions to the economy.

Chitsaz et al. (2019) defined human capital and social capital as significant factors to develop entrepreneurial activities in rural area. Social capital includes networking, trust, cooperation, participation, equality, responsibility and responsive, and commitment and collaboration between community members. While, human capital includes knowledge, skill and self-efficacy. BUMDes has similar characteristics with the concept of ethnic entrepreneurship. Ramadani et al. (2014) described ethnic entrepreneur characteristics such as lower levels of education, strong economic reasons, unique management methods based on their culture and structure of enterprises, less entrepreneurial/ management experience, business supported by informal sources like personal networks and their communities. Finding a third party becomes a solution to deliver benefit for communities. For example, the development of the village's infrastructure requires involvement from different actors so that BUMDes can focus on developing their business. This aims to return the rural initial investment and allocate it as a source of development funds for communities' welfare.

The model pillars in Figure 2 was developed based on the Chatterjee et al. (2017) that defined the growth of entrepreneurship in rural areas are influenced by human quality, financial and physical capital. The model suggests collaboration between Central Government, Provincial Government and Regency Government. Ja'fari, Hoseinzadeh, \& Ahmadian (2017) suggested that governments should strengthen their role in entrepreneurship developments. In West Java, the Regency Government does not have a clear controlled and evaluated program to be implemented in each BUMDes. BUMDes is a village business institution managed by the community and village government to strengthen the village economy and build social cohesion of the community, formed based on the needs as well as potential of the village (Sudaryana, 2016). The research suggested that the government 


\section{ENTREPRENEURSHIP AND SUSTAINABILITY ISSUES}

ISSN 2345-0282 (online) http://jssidoi.org/jesi/

2020 Volume 8 Number 1 (September)

http://doi.org/10.9770/jesi.2020.8.1(48)

offers mentoring sessions for entrepreneurship and youth education by university professors. Entrepreneurship growth is also positively influenced by the motivation, socio-cultural and skill factors. Therefore, empowerment programs that consist of those factors should be conducted in the rural area intensively. Azzahra \& Dhewanto (2015) suggested training materials for entrepreneurship development program in the rural area need to cultivate entrepreneurial motivation and basic entrepreneurial knowledge.

The proposed model is based on an analysis of case studies from 3 BUMDes in West Java. The uniqueness of the case study approach does not require a large sample. Therefore, this proposed model cannot be generalized. However, this model can be applied to BUMDes in Indonesia which have similar characteristics. The implementation of this model requires intervention from the central government. The central government should use its power to engage major state-owned enterprises to establish small industrial workshops in rural centers (Ja'fari et al, 2017). Therefore, programs for the targeted provincial government should be prepared. By adopting the new model as a strategic model, the implementation could assist BUMDes to achieve the eight goals factors more effectively: improving rural economy growth, opening job opportunity, increasing community income and locally-generated revenue for village's income, optimizing rural assets towards communities welfare, increasing community efforts in managing rural's economic potencies, improving community welfare through public services improvement and rural economic equitability and growth, creating market and network opportunities to support the needs of community services, and developing business plan by cooperate with a third party. The success of BUMDes program does not only affect the community and villages but also affect the national economic growth.

\section{Conclusion and Research Implications}

This study focused on the rural entrepreneurship case studies of three BUMDEs in West Java Province. The results showed that the performance of BUMDes in three regencies in West Java had been managed appropriate. This study proposes sustainability dimensions to improve the performance of BUMDes so that they can proceed their functions effectively and sustainably. The evaluation results show three sustainability dimensions in rural entrepreneurship performance that must be implemented by BUMDes, namely economic sustainability, social sustainability and market sustainability. As a rural business agency that adopts social entrepreneurship, BUMDes has the disadvantage of synergizing the stakeholders in managing BUMDes. While ideally, BUMDes management is a responsibility that involves the collaboration of stakeholders.

This study proposes a rural entrepreneurship model that involves stakeholder collaboration. This model aims to maintain the sustainability of BUMDes for the rural economy and community growth. The stakeholder collaboration model can be a solution to improve the success of BUMDes performance. We find that each BUMDes has difference potential of local resources. The proposed model suggests BUMDes to find an appropriate approach in managing potential local resources (human, institutional and physical) using stakeholder collaboration. BUMDes need to increase community participation in economic growth in rural areas and must encourage third parties to support BUMDes investments in business and public services. One way is to involve a third party as a resource partner, thus BUMDes will have better access to advance their local resources. BUMDes also needs to expand its market and network. The action needs to be initiated by the provincial or central government to involve BUMDes and stakeholders in creating new market potential.

This novel study implication guide policymakers towards the sustainability of rural entrepreneurship through BUMDes activities. This rural entrepreneurship model considers that the diversity of potential resources in each region is different, so this model is appropriate to be used to explore the potential of local resources in rural areas through the implementation of the BUMDes program. 


\section{ENTREPRENEURSHIP AND SUSTAINABILITY ISSUES}

ISSN 2345-0282 (online) http://jssidoi.org/jesi/ 2020 Volume 8 Number 1 (September) http://doi.org/10.9770/jesi.2020.8.1(48)

Limitation in this research is related to time series and research locations; for further study, we suggest doing longitudinal research and expanding research locations on a national scale. The implementation of BUMDes in three areas has not been able to reflect the success of BUMDes performance. The results of this study propose a collaborative model for the development of rural entrepreneurship that can be implemented in other provinces in Indonesia which has similar characteristics to the case studies of this research. In addition, the output of this study can be implemented for similar rural entrepreneurship programs by other developing countries.

\section{Acknowledgment}

The authors would like to thank to Bandung Institute of Technology, Indonesia who provide P3MI research grant.

\section{References}

Alheet, A. F. 2019. Investigating the relationship between entrepreneurial activity and economic growth: a case of Middle East, Entrepreneurship and Sustainability Issues, 7(2): 1036-1047. http://doi.org/10.9770/jesi.2019.7.2(17)

Ansari, B., Mirdamadi, S. M., Zand, A., \& Arfaee, M. (2013). Sustainable entrepreneurship in rural areas. Research Journal of Environmental and Earth Sciences, 5(1), 26-31. http://doi.org/10.19026/rjees.5.5635

Autio, E., Kenney, M., Mustar, P., Siegel, D., \& Wright, M. 2014. Entrepreneurial innovation: The importance of context. Research policy, 43(7): 1097-1108. https://doi.org/10.1016/j.respol.2014.01.015

Azzahra, S., \& Dhewanto, W. 2015. Entrepreneurship training for community in rural area: Motivation and knowledge of entrepreneurship, Advanced Science Letters, 21(6): 1858-1862. https://doi.org/10.1166/asl.2015.6137

Baierl, R., Grichnik, D., Spörrle, M. and Welpe, I.M., 2014. Antecedents of social entrepreneurial intentions: The role of an individual's general social appraisal, Journal of Social Entrepreneurship, 5(2): 123-145. https://doi.org/10.1080/19420676.2013.871324

Bumdes.id. 2019. File Referensi BUMDES, 10 August 2019. Retrieved from https://bumdes.id/id/download

Chatterjee, R., Mukherjee, D., Chakraborty, G., \& Deb, M. A. K. 2017. Factors Influencing Growth of Rural Entrepreneurship in Tripura: A Socio-Economic Perspective, The Journal of Innovations, 12(1): 47-57. https://doi.org/10.1016/j.jrurstud.2012.07.002

Chitsaz, E., Tajpour, M., Hosseini, E., Khorram, H., Zorrieh, S. 2019. The Effect of Human and Social Capital on Entrepreneurial Activities: A Case Study of Iran and Implications, Entrepreneurship and Sustainability Issues 6(3): 1393-1403. https://doi.org/10.9770/jesi.2019.6.3(24)

Creswell, J. W., 2013. Qualitative inquiry and research design: Choosing among five approaches.Thousand Oaks, CA: Sage

Dhewanto, W., Lantu, D. C., Herliana, S., \& Permatasari, A. 2016. The obstacles for science technology parks in a developing country, International Journal of Technological Learning, Innovation and Development, 8(1): 4-19. https://doi.org/10.1504/IJTLID.2016.075180

Dhewanto, W., Prasetio, E. A., Ratnaningtyas, S., Herliana, S., Chaerudin, R., Aina, Q., \& Rachmawaty, E. 2012. Moderating effect of cluster on firm's innovation capability and business performance: A conceptual framework, Procedia-Social and Behavioral Sciences, 65: 867-872. https://doi.org/10.1016/j.sbspro.2012.11.212

Drucker, P. 2014. Innovation and entrepreneurship, London, UK: Routledge.

Gioia, D. A., Corley, K. G., \& Hamilton, A. L. 2013. Seeking qualitative rigor in inductive research: Notes on the Gioia methodology, Organizational research methods, 16(1): 15-31. https://doi.org/10.1177/1094428112452151

Goetz, S. J., Partridge, M., Deller, S. C., \& Fleming, D. A. 2010. Evaluating US rural entrepreneurship policy, Journal of Regional Analysis \& Policy, 40(1): 20-33. 


\section{ENTREPRENEURSHIP AND SUSTAINABILITY ISSUES}

ISSN 2345-0282 (online) http://jssidoi.org/jesi/ 2020 Volume 8 Number 1 (September)

http://doi.org/10.9770/jesi.2020.8.1(48)

Goyal, S., \& Sergi, B. S. 2015. Social Entrepreneurship and Sustainability--Understanding The Context And Key Characteristics. Journal of Security \& Sustainability Issues, 4(3). http://dx.doi.org/10.9770/jssi.2015.4.3(7)

Gustafsson, J. 2017. Single case studies vs. multiple case studies: A comparative study. Academy of Business. Engineering and Science, Halmstad University Sweden, 1-15. Retrieved from https://pdfs.semanticscholar.org/ae1f/06652379a8cd56654096815dae801a59cba3.pdf

Issa, F. O., \& Lawal, A. O. 2014. One-village one-product (OVOP): A tool for sustainable rural transformation in Nigeria. Nigerian Journal of Rural Sociology, 14(2202-2019-823), 48-63. http://doi.org/10.22004/ag.econ.287174

Ja'fari, H., Hoseinzadeh, M., \& Ahmadian, M. A. 2017. Effective factors in rural entrepreneurship development: A case study of villages in the central district of Bardaskan city, Ukrainian Journal of Ecology, 7(4): 330-339. https://doi.org/10.15421/2017_124

Kania, I., Akbar, G. G., \& Budiman, M. 2019. Causative Factors of Indonesia's Rural Areas' Low Funding. In First International Conference on Administration Science (ICAS 2019). Advances in Social Science, Education and Humanities Research, Atlantis Press, 343, 388-390. https://doi.org/10.2991/icas-19.2019.80

Kurokawa, K. 2009. Effectiveness and limitations of the 'One Village One Product'(OVOP) approach as a government-led development policy: Evidence from Thai 'One Tambon One Product'(OTOP), Studies in regional science, 39(4): 977-989. https://doi.org/10.2457/srs.39.977

Kusuma, G. H., \& Krisnadewara, P. D. 2019. Innovation Challenges of Village-owned Enterprises, KINERJA, 23(1): 54-66. https://doi.org/10.24002/kinerja.v23i1.2130

Larasdiputra, G. D., Anggiriawan, P. B., Kawisana, P. G. W. P., \& Putra, I. G. B. N. P. 2019. The Role of Village Owned Enterprises in Increasing the Rural Economy, International Journal of Advances in Social and Economics, 1(2): 60-66. https://doi.org/10.33122/ijase.v1i2.41

Luda, S. 2011. Sustainable Rural Entrepreneurship: A Case in Hungary. Journal of Environmental Sustainability, 1(1), 7. https://doi.org/10.14448/jes.01.0007

McElwee, G. \& Atherton, A. 2011. Rural entrepreneurship. In L.P. Dana ed., World encyclopedia of entrepreneurship, pp. 377-384, Cheltenham: Edward Elgar.

Meera, S., \& Vinodan, A. 2018. Exploring the Potential for Rural Entrepreneurship through Integrated Community-based Intervention Strategies. Vision, 23(1), 70-79. https://doi.org/10.1177/0972262918822165

Ministry of Villages, Development of Underdeveloped Areas, and Transmigration. 2020. Daftar Badan Usaha Milik Desa. Kementerian Desa, Pembangunan Daerah Tertinggal, dan Transmigrasi, Indonesia, retrieved from http://datin.kemendesa.go.id/simpora/rep_bumdessmry.php

Muñoz, P., \& Kimmitt, J. 2019. Rural entrepreneurship in place: an integrated framework, Entrepreneurship \& Regional Development, 31(9-10): 842-873. https://doi.org/10.1080/08985626.2019.1609593

Müller, S., \& Korsgaard, S. 2018. Resources and bridging: the role of spatial context in rural entrepreneurship, Entrepreneurship \& Regional Development, 30(1-2): 224-255. https://doi.org/10.1080/08985626.2017.1402092

Natsuda, K., Igusa, K., Wiboonpongse, A., \& Thoburn, J. 2012. One Village One Product-rural development strategy in Asia: the case of OTOP in Thailand. Canadian Journal of Development Studies/Revue canadienne d'études du développement, 33(3), 369-385. https://doi.org/10.1080/02255189.2012.715082

Olafsen, E., \& Cook, P. A. 2016. Growth entrepreneurship in developing countries: A preliminary literature review. Washington, DC: The World Bank Group.

One Village One Company. 2020. One Village One Company. West Java Provincial Government. Retrieved from https://ovoc.jabarprov.go.id/.

Polo-Peña, A. I., Frías-Jamilena, D. M., \& Rodríguez-Molina, M. Á. 2012. Marketing practices in the Spanish rural tourism sector and their contribution to business outcomes, Entrepreneurship \& Regional Development, 24(7-8): 503-521. https://doi.org/10.1080/08985626.2011.617787 


\section{ENTREPRENEURSHIP AND SUSTAINABILITY ISSUES}

ISSN 2345-0282 (online) http://jssidoi.org/jesi/ 2020 Volume 8 Number 1 (September)

http://doi.org/10.9770/jesi.2020.8.1(48)

Pratono, A. H., Prima, D. A., Sinaga, N. F. N. T., Permatasari, A., Ariani, M., \& Han, L. 2020. Crowdfunding in digital humanities: some evidence from Indonesian social enterprises. Aslib Journal of Information Management. 72(2): 287-303. https://doi.org/10.1108/AJIM-05$\underline{2019-0123}$

Purbasari, R. P., Soeling, P. D., \& Wijaya, C. W. 2019. An Entrepreneurial Ecosystems Approach to Encouraging Local Economic Development through a Village-Owned Enterprises Policy (A Case Study of Indonesian Village-Owned Enterprises (BUMDes)), Archives of Business Research, 7(4): 254-264. https://doi.org/10.14738/abr.74.6475

Ramadani, V., Rexhepi, G., Gërguri-Rashiti, S., Ibraimi, S., \& Dana, L. P. 2014. Ethnic entrepreneurship in Macedonia: the case of Albanian entrepreneurs, International Journal of Entrepreneurship and Small Business, 23(3): 313-335. https://doi.org/10.1504/IJESB.2014.065525

Raudeliūniené, J., Tvaronavičienè, M., \& Dzemyda, I. (2014). Towards economic security and sustainability: key success factors of sustainable entrepreneurship in conditions of global economy. Journal of Security and Sustainability Issues, 3, 71-79. http://dx.doi.org/10.9770/jssi.2014.3.4(7)

Saunders, M. N., \& Lewis, P. 2012. Doing research in business \& management: An essential guide to planning your project. New York: Pearson.

Sudaryana, B. 2016. The Model of Development Policy Implementation Village Owned Enterprises in Indonesia. In 1st International Conference on Social and Political Development (ICOSOP 2016). Advances in Social Science, Education and Humanities Research (ASSEHR), Atlantis Press, 81, 1-29. https://doi.org/10.2991/icosop-16.2017.3

Thanh, L. H., Nhat, L. T., Dang, H. N., Ho, T. M. H., \& Lebailly, P. 2018. One Village One Product (OVOP)—A Rural Development Strategy and the Early Adaption in Vietnam, the Case of Quang Ninh Province, Sustainability, 10(12): 4485. https://doi.org/10.3390/su10124485

Tousi, Ramezan \& Jamshidi, Ali Reza \& Taghdisi, Ahmad (2014). The rural entrepreneurship and determining the effective elements on it, Research and Rural Planning, 3(8), 1-12. https://doi.org/10.22495/rgcv8ilart4

Welter, F. 2011. Contextualizing entrepreneurship - conceptual challenges and ways forward, Entrepreneurship Theory and Practice, 35: 165-184. https://doi.org/10.1111/j.1540-6520.2010.00427.x

Yang, J., Černevičiūtè, J., \& Strazdas, R. 2020. The sustainable development of rural troupes under the rural vitalization strategy in China, Entrepreneurship and Sustainability Issues, 7(3): 1951-1962. https://doi.org/10.9770/jesi.2020.7.3(34)

Yin, R. K. (2014). Case study research: Design and methods (applied social research methods). Thousand Oaks, CA: Sage publications.

Zahra, S. A., Wright, M., \& Abdelgawad, S. G. 2014. Contextualization and the advancement of entrepreneurship research, International Small Business Journal, 32(5): 479-500. https://doi.org/10.1177/0266242613519807 


\section{ENTREPRENEURSHIP AND SUSTAINABILITY ISSUES}

ISSN 2345-0282 (online) http://jssidoi.org/jesi/ 2020 Volume 8 Number 1 (September) http://doi.org/10.9770/jesi.2020.8.1(48)

Wawan DHEWANTO is an associate professor at School of Business and Management (SBM), Institut Teknologi Bandung (ITB), Indonesia. Previously, he was director of bachelor of entrepreneurship SBM ITB, head of entrepreneurship and technology management research group SBM ITB and division head of entrepreneurship development of the Institute of Innovation and Entrepreneurship (LPIK) at the university. His areas of interest include entrepreneurship ecosystem, small and medium enterprise, and digital start-up.

ORCID ID: $\underline{\text { http://orcid.org/0000-0002-6705-5191 }}$

Sudrajati RATNANINGTYAS is a Professor and Head of Entrepreneurship and Technology Management Research Group at School of Business \& Management ITB, Indonesia. She has expertise in Bio-industry Management and Entrepreneurship for SME's. Her current research focuses on the sustainability of family business.

ORCID ID: $\underline{\text { https://orcid.org/0000-0001-7731-1868 }}$

Anggraeni PERMATASARI is a full-time lecturer at the Faculty of Business, President University, Indonesia. She works as a Senior Lecturer within the Entrepreneurship subject group and specializes in Social Entrepreneurship and SME's development. Anggraeni has a 6year teaching experience in entrepreneurship, social innovation, corporate social responsibility and strategic management. She also has experience in designing entrepreneurship development program in rural areas. Her current research focuses on creative and social entrepreneurship development.

ORCID ID: https://orcid.org/0000-0001-8538-2463

Grisna ANGGADWITA is an assistant professor at School of Economics and Business, Telkom University, Indonesia. She teaches courses in entrepreneurship, small business management, e-commerce and business process. Her research interests include entrepreneurial intention, women entrepreneurship, business incubator, technology management, and innovation management. She is an active researcher who has published more than 100 articles in leading international and national journals as well as international proceedings. She received the Award for Excellence 2019 - High Commended Paper by Emerald Group Publishing (Journal of Science and Technology Policy Management).

ORCID ID: $\underline{\text { https://orcid.org/0000-0003-1503-9146 }}$

Eko Agus PRASETIO is full-time lecturer at SBM-ITB, Indonesia. He has more than 10 years of professional experiences in innovation and new product development function in manufacturing companies in Indonesia, Japan and the Netherlands. His research interests are in the area of technological change, disruptive technology and innovation, and innovation management.

ORCID ID: https://orcid.org/0000-0002-2600-8778

Make your research more visible, join the Twitter account of ENTREPRENEURSHIP AND SUSTAINABILITY ISSUES: @Entrepr69728810

Copyright (C) 2019 by author(s) and VsI Entrepreneurship and Sustainability Center

This work is licensed under the Creative Commons Attribution International License (CC BY).

http://creativecommons.org/licenses/by/4.0/

(c) (i) Open Access 